\title{
平面構成・希望用途からみた座敷への住要求構造の分析 \\ 現代における住宅計画のための室要求構造の解明に関する研究 その 1 \\ A STUDY ON THE NEEDS FOR “ZASHIKI” FROM THE VIEW \\ OF THE PLAN TYPE AND FUNCTION
}

A research of relations between plan-types and function for contemporary house planning Part 1

切原舞子*, 鈴木義弘**, 岡 俊江 ***

\section{Maiko KIRIHARA, Yoshihiro SUZUKI and Toshie OKA}

Based on the analysis of consistency between the plan of house planning one now lives in and the plan of house planning that is considered desirable by the dwellers, this paper intends to grasp how dwellers like to sit in "zashiki". Results of analysis revealed dwellers yet seem to stick to keep "tokonoma". As for the plan type of "zashiki", there lies a noticeable dissociation (inconsistency) between dwelling plan and selection plan, vivid and increasing tendency in this respect is separation from living room as well as from "one room" to "two rooms".

Keywords : zashiki, receiving guests, family living, house planning, detached house 座敷, 接客, 家族生活, 住宅計画, 独立住宅

1.はじめに

\section{1 研究の背景と目的}

本研究は、現代の独立住宅に対する室要求構造を明らかにするこ とを目的としており、接客空間注 1) と家族空間、および私的空間の 相互関係性を捉え、住まい手の多様な要求に対応可能な住宅計画の 知見を示すものである。本稿ではまず、座敷注 2) および和室の今日 的存在意義と、住まい手の求める平面構成について考察する。

我が国の住宅の平面構成の変容は、「接客空間とだんらん空間の領 域構成の変化」1）注 3) と考えることができ、独立住宅における接客 空間としては、座敷がこれに位置づけられてきたといえよう。伝統 的に、座敷とこれに連続する次の間の「続き間座敷」は広く普及し、 慶年祭祀の多人数接客を考慮して配置され、日常的には主人の居室 および寝室として、時には客の宿泊にも使われてきた。しかし戦後 の食寝分離、就寝分離を重視した計画論において、座敷はその存在 を無視され、戦後の公的供給の集合住宅の設計においては考慮され なかった。しかしながらその一方で、民間供給の独立住宅には厳然 と継承されてきた。先行研究を示すと、1980 年代に実施した調査 (以 下、[80’]） 注 4) では $85.0 \% 、 2000$ 年代の調查（以下、[00’’]）注 5) で も $63.8 \%$ が座敷を設けている。ただし、その平面構成についてこの 間の変容をみると、和室二室の「続き間座敷」は激減し、これに対
してリビングルーム注 6) と座敷が続き間のタイプが急伸しているの が現状である。また[80’]では対象者の「住まい方」調査より、座敷 を接客空間に位置づけることができたが注 7)、近年の研究では ${ }^{5) ~ 7) 、 ~}$ 来客の応対はリビングルームで行われる場合が多い。すなわち、現 代においても座敷へのニーズが認められるが、その存在基盤は必ず しも接客機能にあるとはいえず、不明瞭である。 接客領域と家族のだんらん領域との関係性に着目した先駆的研究とし ては、まずは鈴木ら (1981 年 $)^{4)}$ による「デュアルリビング」の提案が特筆さ れるが、この他、江上 $(1989 \text { 年 })^{5)}$ の研究や、近年では樋口 $(1994 \text { 年 })^{6)}$ が、 座敷とリビングルーム注 ${ }^{8)}$ に対する住まい手の価值づけの違いが領域区 分の違いをもたらすといら仮説の実証を試みている。また笠嶋ら（1992 年） ${ }^{7)}$ は、来客の応対や宿泊位置を含む生活行為の分析から、ライ フステージ別の要求とその変化についての考察を行っている。盢敷 きという床面様式に対しては、扇田ら（1978 年） ${ }^{8)}$ が生産動向と現 状と住まい手の要求の関係から今後の展望を述心゙、近年のものとし ては平井らの研究（2000 年） 9)が挙げられる。

これらの成果を念頭におきながら、本研究は独立住宅を対象にし、 先行研究に引き続き、歴史的流れの中の発展段階として現代を位置 づけ、平面構成と用途についての住まい手の希望も考慮して、座敷 への住要求構造を捉えるものである。

\footnotetext{
* 大分大学大学院工学研究科 博士後期課程 $\cdot$ 工修

* 大分大学工学部福祉環境工学科 准教授・博士 (人間環境学)

*** 九州女子大学家政学部人間生活学科 教授.工博
}

Graduate Student, Department of Eng., Graduate School of Eng., Oita Univ., M. Eng. Assoc. Prof., Faculty of Eng., Oita Univ., Ph. D.

Prof., Faculty of Home Economics, Kyushu Women's Univ., Dr. Eng. 


\section{2 研究の方法}

本研究では座敷について、平面構成と用途それぞれの現状と希望 の整合性を捉え、この要因を両者の関係から考察する。分析にあた り、現状の住まいの平面構成を「居住プラン」ここれに対し、住まい 手が望ましいと選択したものを「選好プラン」と呼称する。本稿で は、両者の整合性、寸なわち一致しているのか、あるいは不一致の 場合にはどのような乘離が生じているのかに着目しながら、その要 因を、座敷への希望用途やライフステージ注9) との関係から考察する。

なお、[00’研究において、床の間を持たない和室のみの住宅が約 3 割を占めていたため、これらの世帯も対象とし、「座敷あり」タイ プと、床の間のない「和室のみ」タイプの比較考察もまじえ、これ らを一括して呼称する場合には、座敷（和室）と表記する。

以上に基づき、本稿は下記で構成している。

1. 居住プランと選好プランの整合性の分析・・・・・・・3 章

2. 座敷（和室）への希望用途についての分析…… 4 章

3. 希望用途とプランタイプとの関係性についての分析・・・・5 章

\section{3 居住プラン・選好プランの類型方法}

独立住宅の類型化の参考となるものとしては、服部 (1980 年) ${ }^{10)}$ 、 近年では森本 $\left(1993\right.$ 年) ${ }^{11)}$ の研究が挙げられる。本研究での平面構 成の座敷（和室）の類型には、先行研究 ${ }^{2)}$ での「接客空間とだんら ん空間が重合して平面構成が発展してきた」という考え方に基づき、 まずはリビングルームとの接続形式で 2 タイプ (「連続型」・分離 型」）に分ける。これに和室の数（「二室型」・「一室型」）、座敷（和 室)へのアクセスの仕方、さらに床の間の有無を考慮して 10 タイプ の類型で、分析を行う〈図 1〉。なお本文では、「和室のみ」は添え 字「和」を付加して、〈分 II 和〉等と表記する。

表 1 調查概要

\begin{tabular}{|c|c|}
\hline \multicolumn{2}{|r|}{ アンケート調査の内容 } \\
\hline 調査対象 & $\begin{array}{l}\text { :1990年以降より分譲された全国9地域の戸建て住宅団地 } \\
\text { 北海道,仙台,千葉,茨木,愛知,富山,大阪,京都,広島,愛媛,高知,福岡,大分 } \\
\text { 2階建てみみ } \\
\text { 総室数4室〜 6室、1階2〜3室、2階2〜3室の規模の住宅を想定 }\end{array}$ \\
\hline 配布期間 & : 2005年7月～8月 2006 年 8 月 9月 $\cdot 2$ 月～3月 \\
\hline 配布数 & $\begin{array}{r}\text { 収集サンプル数: 703件 (回収率:8.6\%) } \\
\text { 本研究有効サン }\end{array}$ \\
\hline
\end{tabular}

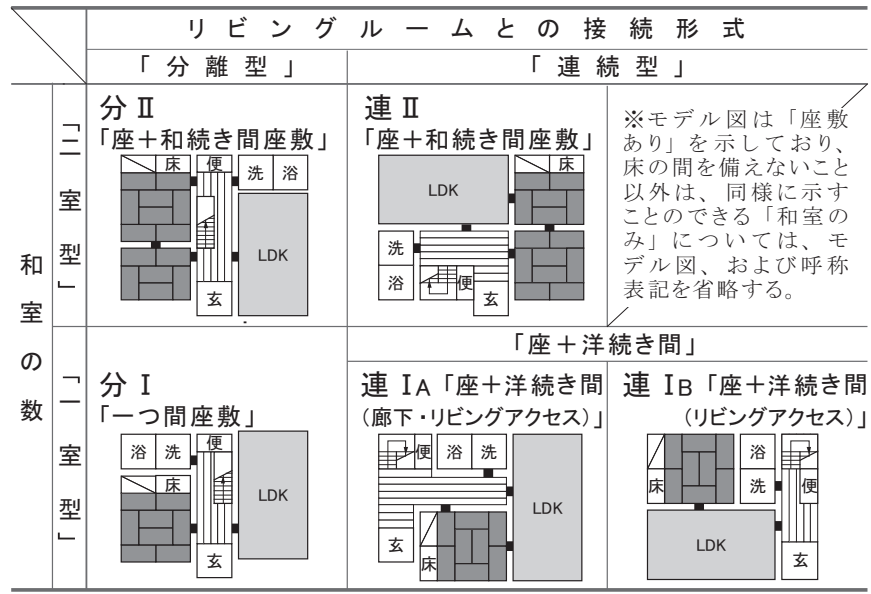

図 1 座敷（和室）の平面構成

\section{2. 調査概要}

\section{1 調査の方法}

調查対象は、1990 年以降に分譲された戸建て住宅団地とし、特定 の地域には限定せず、地方区分（北海道、東北、関東、東海、北陸、近 畿、中国、四国、九州)に従って、全 9 地域の各主要都市に所在寸る団 地を選定した。戸別訪問によりアンケート調査票を配布し、郵送での 回収を行った〈表 1〉。有効サンプルは、和室をもたない事例を除い た 369 件である注 10$)$

\section{2. 対象住宅・対象居住者概要}

対象住宅は、延床面積 $82.5 \mathrm{~m}^{2} \sim 184.8 \mathrm{~m}^{2}$ 、平均 $133.3 \mathrm{~m}^{2 \text { 注 }}$ 11)、注文住 宅 64.5\%、および建売住宅 34.1\%（不明 5 件）である。居室数注 ${ }^{12}$ ） は 1 階 2 室 $90.0 \% 、 2$ 階 3 室 $69.1 \%$ が多く、1 階に座敷（和室）1 室と LDK、 2 階に 3 室を持つ「2-3」(235 件) が約 6 割を占める〈表 2$\rangle$ 。

床の間を備えた「座敷あり」は、全体では 82.7\%（305 件）、地域 別には 6 9 割と異なるが、本稿では全対象地域に共通する事象とし て指摘できる点についての分析考察を示す〈図 2〉。

家族構成は、複合家族 32 件 $(8.7 \%)$ も含んでおり、世帯主年齢 は 25 歳から 77 歳と幅広い。ライフステージ別では〈表 3 、子を持 つ「分寝前」から「子世帯同居」では、より後者で高年齢層が多い。また、 同居家族人数を捉えると、子が独立別居前である「分寝前」、「分寝以 降」は、3、4、5 人に三分される。

表 2 室数構成

\begin{tabular}{|c|c|c|c|c|c|c|c|c|c|}
\hline \multicolumn{10}{|c|}{ (1階室数 -2 階室数) } \\
\hline $2-1$ & $2-2$ & $2-3$ & $2-4$ & $2-5$ & 3-2 & $3-3$ & $3-4$ & 3-5 & 総計 \\
\hline 4 & 51 & 235 & 41 & 1 & 5 & 20 & 11 & 1 & 369 \\
\hline 1.1 & $\frac{13.8}{3}$ & $\frac{63.7}{2.90 .7}$ & 11.1 & 0.3 & 1.4 & $\begin{array}{r}5.4 \\
37\end{array}$ & $\frac{3.0}{0.0}$ & 0.3 & $\begin{array}{r}369 \\
1000\end{array}$ \\
\hline
\end{tabular}

\begin{tabular}{|c|c|c|c|c|c|}
\hline & & $\langle$ 〈件〉 & $\begin{array}{l}\text { 「床の間」有り } \\
=「 \text { 座敷あり」 }\end{array}$ & $\begin{array}{l}\text { 「床の間」無し } \\
=「 \text { 和室のみ」 }\end{array}$ & $\begin{array}{l}\text { 平均延床 } \\
\text { 面積 }\left\langle\mathrm{m}^{2}\right\rangle\end{array}$ \\
\hline 総 & & 369 & & 82.7 & 133.3 \\
\hline & 北海道 & 17 & \begin{tabular}{|l|l|}
64.7 & \\
\end{tabular} & 35.3 & 131.6 \\
\hline & 東北 & 21 & 66.7 & 33.3 & 136.9 \\
\hline & 関東 & 28 & 67.9 & 32.1 & 128.8 \\
\hline & 北陸 & 18 & & \begin{tabular}{l|l|}
83.3 & \\
\end{tabular} & 135.4 \\
\hline 㞼 & 東海 & 42 & & \begin{tabular}{|l|l|}
90.5 & 9.5 \\
\end{tabular} & 136.2 \\
\hline f & 近畿 & 26 & & 80.8 & 132.7 \\
\hline & 中国 & 46 & & \begin{tabular}{l|l|}
78.3 & \\
\end{tabular} & 137.8 \\
\hline & 四国 & 22 & & \begin{tabular}{|l|l|}
90.9 & 9.1 \\
\end{tabular} & 135.3 \\
\hline & 九福岡 & 72 & & \begin{tabular}{|l|l|}
88.9 & 11.1 \\
\end{tabular} & 132.1 \\
\hline & 州大分 & 77 & & \begin{tabular}{l|l|}
87.0 & 13.0 \\
\end{tabular} & 131.3 \\
\hline
\end{tabular}

図 2 床の間の有無と平均延床面積

表 3 ライフステージの概要

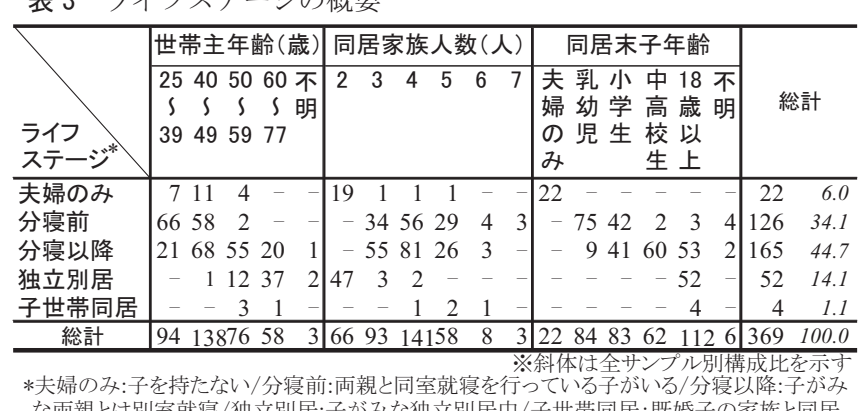




\section{3. 居住プランと選好プランの整合性の分析}

\section{1 和室および床の間の要否}

分析対象は「和室あり」だが、選好プランでは「和室なし」がわ

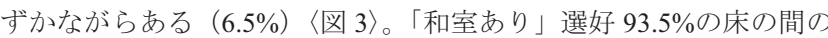
有無を考慮すると、「座敷あり」71.3\%（263 件）は居住プラン $82.7 \%$ （305 件）に比べて少なく、「和室のみ」22.2\%（82 件）が居住プラ ン 17.3\%（64 件）に比べ増加している点が指摘できる。 選好プランを居住プラン別に捉えると、以下 6 類型となる。 居住プラン「座敷あり」の 305 件について

i .「ZZ」：(237 件)「座敷あり」を選好した一致層

ii.「ZW」：(51 件)「和室のみ」を選好した不一致層

iii.「Zn」：(17 件)「和室なし」を選好した不一致層

居住プラン「和室のみ」の 64 件について

iv .「WZ」：(26 件)「座敷あり」を選好した不一致層

V .「WW」：(31 件)「和室のみ」を選好した一致層

vi.「Wn」：(7 件)「和室なし」を選好した不一致層

「座敷あり」居住者のうち $77.7 \%$ はZZ」で依然座敷を希望する いわば床の間温存層であるが〈図 4〉、16.7\%（51 件）は「ZW」の

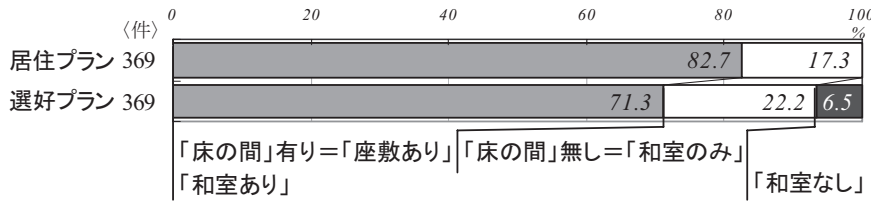

図 3 居住・選好プランの床の間の有無

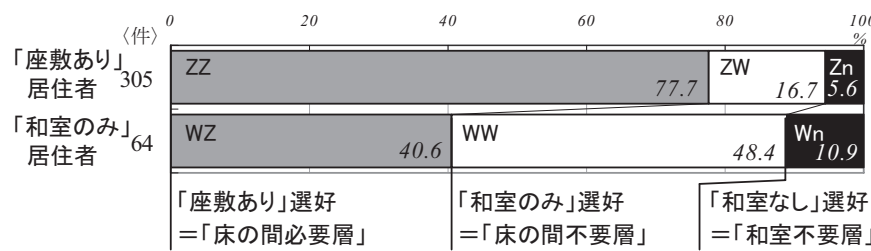

図 4 和室および床の間の要否
「床の間不要層」である。一方「和室のみ」居住者は「WW」の一 致層と「WZ」の不一致層とにほぼ二分される。すなわち座敷のな い住宅を取得したが、できれば床の間を設けたいという居住者が $40.6 \%$ タられ、注目に值する。

\section{2 プランタイプ}

\section{1）居住プランと選好プランの傾向}

居住プランの 39.6\%（146 件）を占める「座+洋続き間〈連 I A〉」 は選好プランでは 25.5\% (94 件) と約 $2 / 3$ に減少し、リビングル ームからのみのアクセスである〈連 I B は 13 件（3.5\%）とわずか である〈表 4 〉。一方「一つ間座敷〈分 I〉」は20.6\%（76 件）で居 住プラン $22.5 \%$ (83 件) との差がなく、「座十和続き間座敷〈分 II 」」 にいたっては、17.3\%（64 件）と居住プランの約 3 倍の值である。

\section{2) 居住プランと選好プランの整合性}

「座敷あり」居住者 306 件のうち、「ZZ」の床の間温存層 237 件 でも、そのプランタイプまでも一致しているのは 4 割（122 件）に 留まる〈表 4〉。居住プラン別に一致層を捉えると、最も供給数の多 い「座十洋続き間〈連 I A 」は 39.0\%（57 件）であり、〈連 I B も 低く（19.5\% 8 件）、供給数では 2 番目に多い「一つ間座敷〈分 I 」 も 47.0\%（39 件）で半数に及ばない。一方「座十和続き間座敷〈分 II 〉」は $68.2 \%$ （15 件）と一致度が高い。

不一致層に着目すると、「二室型」はいずれも「座敷あり」選好で ある。一方、「一室型」のうち〈分 I 〉居住者では〈分 II へ の選好 が 19.3\%であり、「連続型」選好（10.8\%）に比べ多い。同様の傾向 が〈連 I A 〉居住者にもいえ、「分離型」選好 $24.0 \%$ に対し、「連続型」 選好が $8.9 \%$ と、〈分 I〉居住者よりもさらに顕著な差を示す。

しかしながらこれら一致度の低い「一室型」不一致層には、そも そも座敷を必要としない「和室のみ」・「和室なし」への選好がいず れも約 2 割みられる。この内訳は、〈分 I 〉居住者の〈分 I 和〉選好

表 4 居住プランと選好プラン

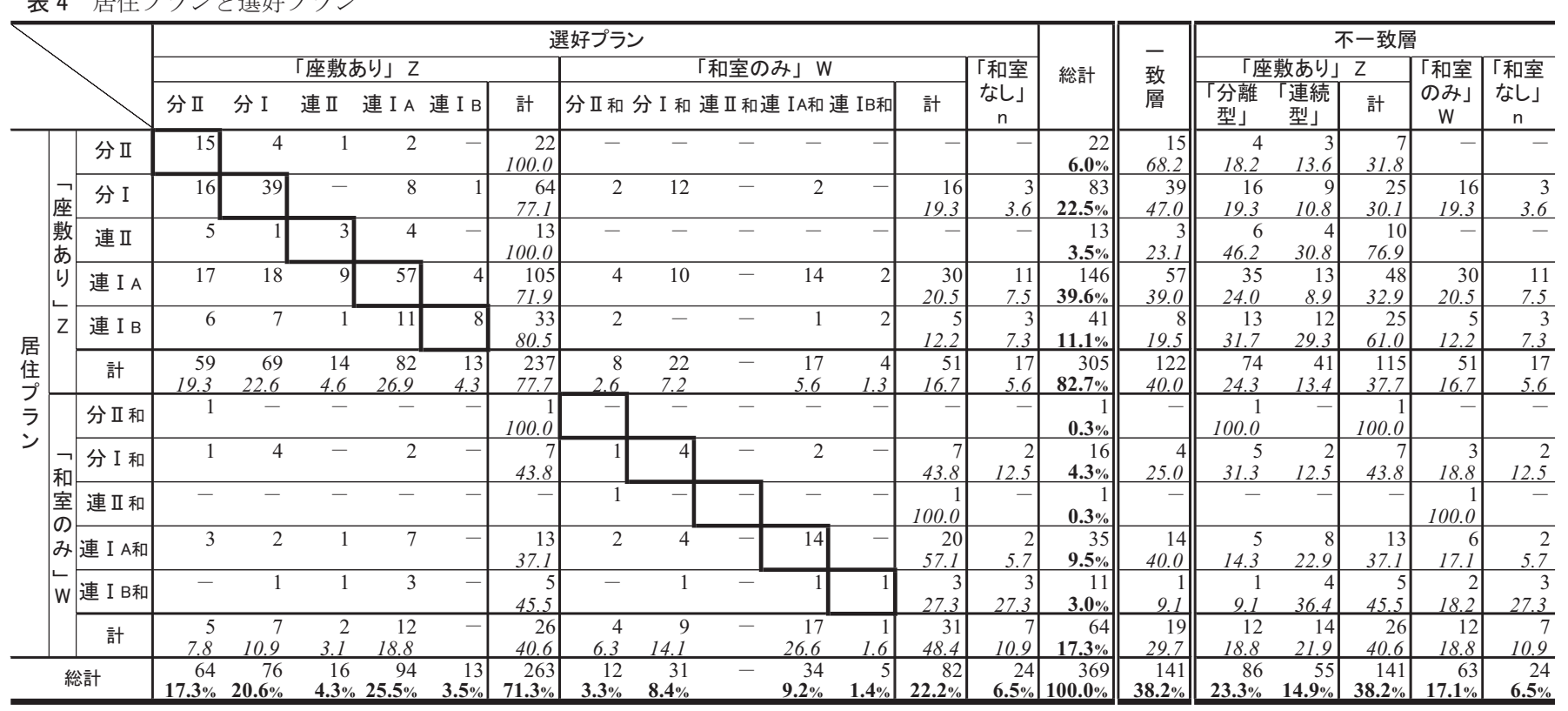


12 件、〈連 I A 居住者の〈連 I A 和〉選好 14 件であり、床の間は不 要とするものの、これを考虑しなければ、現状のプランタイプを支 持している層も存在しているということがわかる。

\section{3）居住・選好プランタイプ不一致層の志向性}

そこで以下では、居住・選好プランタイプの不一致層の志向性を 捉え、その上で床の間の要否との関係性を捉えることとする。

プランタイプ不一致層の志向性は、次に示す、リビングルームと の接続形式、および和室数についての居住プランと選好プランの関 係性の組み合わせで、整理することができる〈図 5$\rangle$ 。

i ．リビングルームとの接続形式について

「分離」志向 : 居住プラン「連続型」選好プラン「分離型」注 13) 「連続」志向 : 居住プラン「分離型」選好プラン「連続型」注 13)

ii . 和室数について

「拡大」志向：居住プラン「一室型」選好プラン「二室型」

「縮小」志向 : 居住プラン「二室型」選好プラン「一室型」

プランタイプ不一致層が 188 件みられ、一致層は「分離型」居住 者 $20.3 \%$ （75 件）、「連続型」居住者 $28.7 \%$ （106 件）、計 49.1\%（181 件）で半数に満たない〈図 6〉。不一致層は、現状よりもリビングル 一ムからの「分離」志向 $17.6 \%$ 、和室数については「一室型」から 「二室型」への「拡大」志向 $8.1 \%$ 、その両方を志向する「分離・拡 大」 $9.8 \%$ と、分離・拡大志向が計 $35.5 \%$ と顕著である。

床の間の要否を考慮すると、床の間温存層「ZZ」の不一致層 $(48.5 \%)$ が求めるのは、38.4\%が座敷の分離・拡大志向であるが、 さらにその志向性を強く示すのが、床の間の要否の面でも不一致層 である「WZ」の「床の間必要層」であり、分離・拡大志向が $46.2 \%$ と最も高く、居住・選好の食い違いが顕著に露呈した結果であると 考えられる。一方「WW」はプランタイプ一致層が $61.3 \%$ と高く、 また「連続型」志向が半数に及ぶ点で傾向を異にするが、それでも 不一致の場合には、分離・拡大を求めていることに変わりはない。

すなわち、全体の傾向としては、座敷（和室）とリビングルーム との連続性確保を求める層も認められるが、「連続型」から「分離型」 への「分離」、らには「一室型」から「二室型」への「拡大」志向 が顕著であり、供給されているプランタイプの構成比とは相反する 傾向を示す点が特筆できる。

\section{3 ライフステージとの関係}

まず、和室および床の間の要否について、「座敷あり」居住者は、 いずれのライフステージでも「座敷あり」選好「ZZ」が 7〜8 割と 一定であり〈図 7〉、「和室のみ」居住者については、サンプル数の 少ない「夫婦のみ」で特異值を示寸他に、差異はみられない〈図 8〉。 選好プランで捉えると、「座敷あり」選好、寸なわち「床の間必要 層」 263 件について、ライフステージ別の顕著な違いをみせるのは、 「座十洋続き間〈連 I A 〉」と「座十和続き間座敷〈分 II 〉」である 〈図 9〉。〈連 I A〉は「夫婦のみ」46.2\%、「分寝前」47.6\%では約半

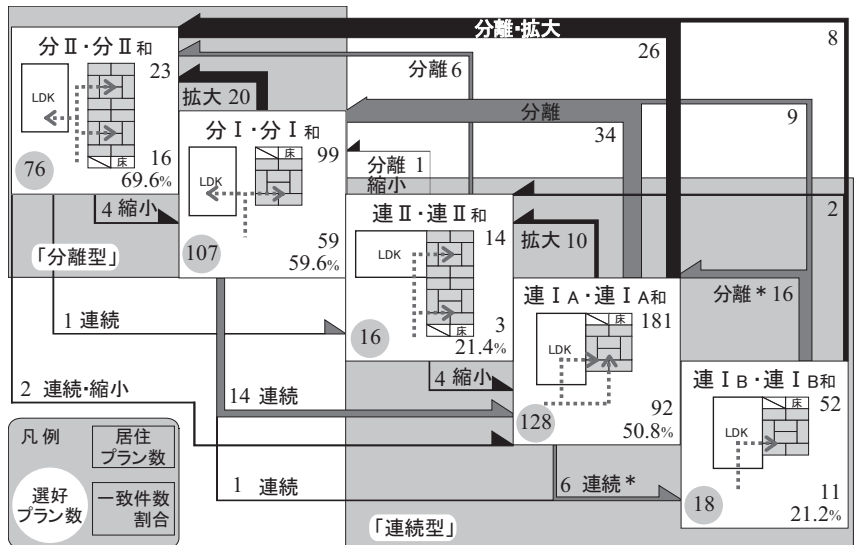

図 5 居住・選好プランの関係

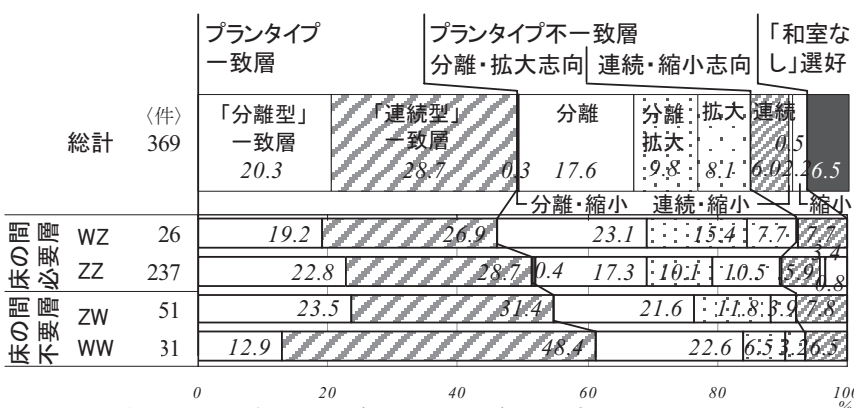

図 6 居住・選好プラン一致層と不一致層の志向性

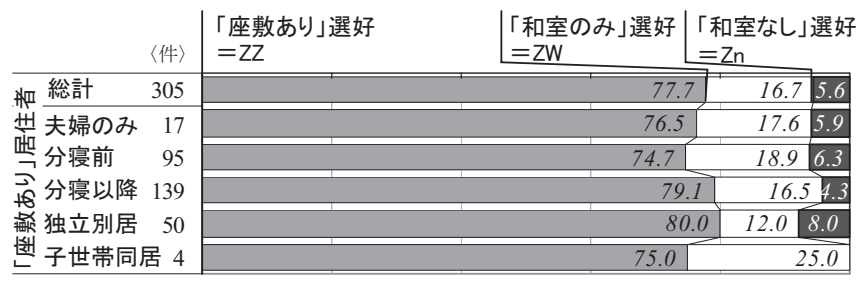

図 7 「座敷あり」居住者 和室および床の間の要否

\begin{tabular}{|c|c|c|c|c|}
\hline & 件〉 & $\begin{array}{l}\text { 「座敷あり」選好 } \\
=W Z\end{array}$ & $\begin{array}{l}\text { 「和室なし」選好 } \\
=W W\end{array}$ & $\begin{array}{l}\text { 「和室のみ」選好 } \\
=W n\end{array}$ \\
\hline \multirow{5}{*}{ 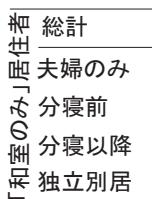 } & 64 & 40.6 & & \begin{tabular}{|l|l|}
48.4 & 10.9 \\
\end{tabular} \\
\hline & 5 & & & 100.0 \\
\hline & 31 & 41.9 & & \begin{tabular}{|l|l|}
45.2 & 12.9 \\
\end{tabular} \\
\hline & 26 & 46 & 2.2 & \begin{tabular}{|l|l|}
46.2 & 7.7 \\
\end{tabular} \\
\hline & 2 & & 50.0 & 50 \\
\hline
\end{tabular}

図 8 「和室の゚み」居住者 和室および床の間の要否 ${ }^{40}$

\begin{tabular}{|c|c|c|c|c|}
\hline 〈件〉 & $\begin{array}{l}\text { 「分離型」選好 } \\
\text { 分 II }\end{array}$ & 分 I & $\begin{array}{l}\lceil\text { 連続型」選好 } \\
\text { 連 II }] \text { 連 I A }\end{array}$ & 連 I B \\
\hline 腼世 総計 & 24.3 & \multicolumn{3}{|c|}{ 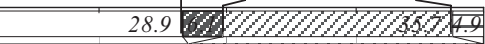 } \\
\hline \multirow{5}{*}{ 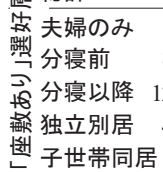 } & 15.4 & & $38.52 Z Z Z$ & $Q_{162}$ \\
\hline & 16.7 & & \multicolumn{2}{|c|}{ 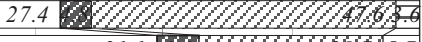 } \\
\hline & \multicolumn{2}{|c|}{27.9} & $31.16 \mathrm{WK}$ & $2 \% \sqrt{5.7}$ \\
\hline & 29 & .3 & $22.0 \angle Q Z Z Z Z$ & WKF 7.3 \\
\hline & & 66.7 & 33.3 \\
\hline
\end{tabular}

図 9 「座敷あり」選好層 選好プラン

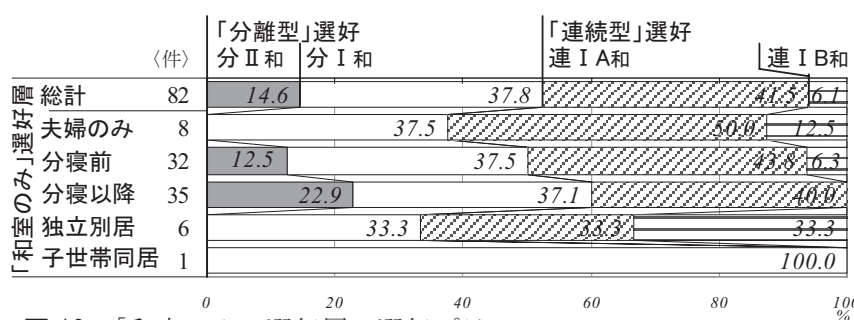

図 10 「和室のみ」選好層 選好プラン 
数を占めるが、「分寝完了」 $28.7 \%$ 、「独立別居」 $31.7 \%$ では $1 / 3$ 以 下である。これに対して〈分II〉は、「夫婦のみ」15.4\%、「分寝前」 $16.7 \%$ に比心゙、「分寝完了」 $27.9 \%$ 、「独立別居」 $29.3 \%$ で高くなって おり、〈連 I A とは反対の傾向を示す。一方、「一つ間座敷〈分 I 〉」 は 2〜3 割と支持が一定している。「和室のみ」選好の「床の間不要 層」 82 件でも、「分寝前」 $12.5 \%$ に比べ「分寝以降」 $22.9 \%$ で〈分 II への希望が高いという同様の傾向が指摘できるが、〈連 I A 〉への希 望は約 4 割と一定であり、「床の間必要層」とは異なる〈図 10〉。

つまり、夫婦のみや、子供が両親と同室就寝をしている期間、あ るいは「和室のみ」を希望する場合には、「連続型」への要求が比較 的高いといえるが、子が分離就寝を終えた後では、「分離型」、中で も「二室型」への支持が高いという特徵がみられる。

\section{4. 座敷 (和室) への希望用途についての分析}

\section{1 座敷（和室）への希望用途}

座敷（和室）への希望用途は、〈図 11〉に示す 10 項目について、 それぞれ 4 段階評定尺度での回答を得た。以下の分析は、これを「希 望あり」と「希望なし」の 2 段階評価に変換したデータを用いる。

\section{1）希望用途の傾向}

座敷（和室）に求める用途（和室不要層を除く 345 件）を捉える と、『日常接客』が最も多く、「応対」 $71.0 \%$ 、「宿泊」 $84.9 \%$ ある 〈図 11〉。また、『行事・慣習』は「仏間」設置 $(69.6 \%)$ 、「法事」 利用 $(64.9 \%)$ がいずれも 6 割以上、家族の「祝い事」への利用も 少ないながら $22.3 \%$ みられる。家族生活』としては、「就寝」 $30.1 \%$ 、

「趣味・仕事」 $24.3 \%$ 、「子遊び」 $19.1 \%$ の主要用途以外にも、多岐 に分かれ、用途を特定しない『予備室』希望も $64.1 \%$ にぼる。

\section{2）接客機能の内訳}

『日常接客』・『行事・慣習』の接客機能は、『日常接客』では「応 対十宿泊」が $66.7 \%$ （230 件）〈表 5〉、『行事・慣習』では「仏間」

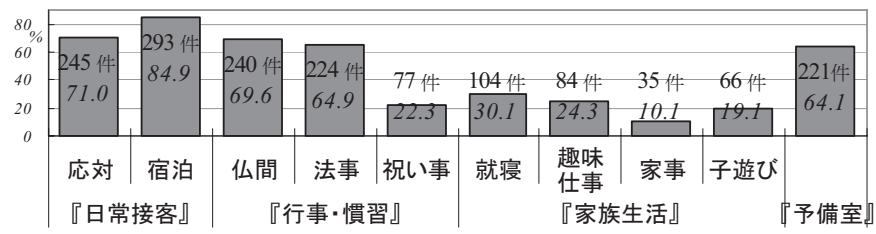

図 11 座敷（和室）への希望用途

表 5 座敷（和室）に求める接客機能の内訳

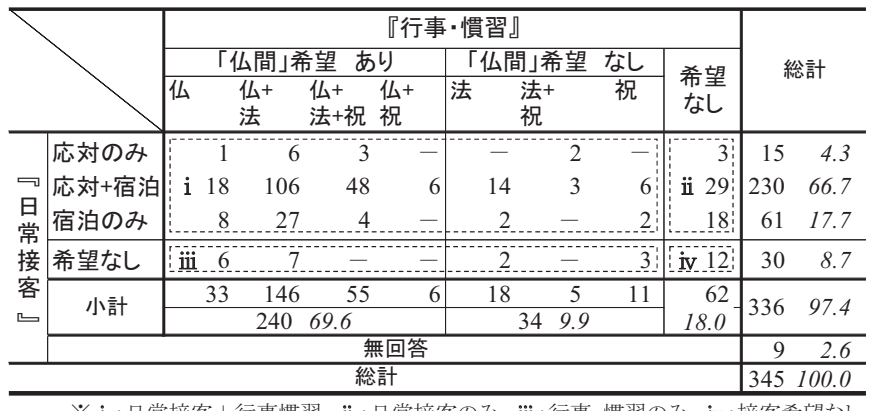

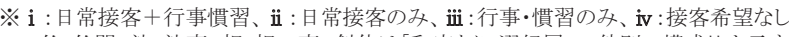
仏:仏間、法: 法事、祝: 祝い事 斜体は「和室あり」選好層345件別の構成比を示寸
希望 69.6\%（240 件）、これに併せて「法事」を希望する場合 58.3\% （201 件）であり、伝統的な用途を継承する志向が支配的である。 組み合わせで捉えなおすと、両方を希望する「日常接客十行事・ 慣習」が $74.2 \%$ （256 件）で最も多い〈表 5〉。また「日常接客のみ」 $14.5 \%$ 、「行事・慣習のみ」5.2\%、の一方のみへの希望もみられ、依 然 9 割以上が座敷（和室）に接客機能を求めている。

\section{3）『家族生活』・『予備室』機能と接客機能との重合性}

『家族生活』希望 184 件のうち、「就寝」56.5\% と「趣味・仕事」 $45.7 \%$ が多い〈表 6〉。両者の有無で捉えると、「就寝」のみ（51 件） が多く、併せて「趣味・仕事」があるのは 28 件である。また「就寝」 なしの 80 件の約 $2 / 3$ (56 件) は、「趣味・仕事」への希望がある。

『予備室』希望との組み合わせでは、『家族生活』希望はなくとも 『予備室』は希望する場合が $27.5 \%$ （95 件）みられる〈表 7$\rangle$ 。 接客機能との重合性で捉えなおすと、次に整理できる〈表 7〉。

i .「接客十家族重合」：173 件 $(50.1 \%)$ 一接客機能と併せて『家 族生活』希望があり、「就寝」のある「接客十就寝」96 件 (27.8\%) と、ない「接客十その他」 77 件 $(22.3 \%)$ に二分する。

ii .「接客十予備室」：92 件 (26.7\%) -『家族生活』希望はなく、 接客機能と併せて『予備室』への希望がある。

iii.「接客の夕」：59 件 (17.1\%) 一接客機能のみを希望する。

iv. 接客機能希望なし：21 件 (6.1\%) -「就寝」のみ 8 件、「そ の他」のみ 3 件、「予備室」のみ 3 件、無回答 7 件。

すなわち、座敷（和室）を必要とした場合であっても、接客専用 に希望するのは、そのうちの $17.1 \%$ みである。

表 6 『家族生活』希望の内訳

\begin{tabular}{|c|c|c|c|c|c|c|c|c|c|c|c|c|c|}
\hline & \multicolumn{9}{|c|}{ 「就寝」 } & \multirow{2}{*}{\multicolumn{3}{|c|}{ 総計 }} \\
\hline & & \multicolumn{5}{|c|}{ 下就寝」あり } & \multicolumn{4}{|c|}{ 「就寝」なし } & & & \\
\hline \multirow{5}{*}{$\begin{array}{l}\text { 家 } \\
\text { 族 } \\
\text { 活 } \\
\text { 活 }\end{array}$} & 「就寝」 & \begin{tabular}{|l|l|}
45 & 12 \\
$(6)$ & $(1)$ \\
\end{tabular} & & & & \begin{tabular}{|l|l|}
2 & 16 \\
$(1)$
\end{tabular} \mid & & & & - & \begin{tabular}{|c|}
96 \\
$(8)$
\end{tabular} & 55.5 & $\begin{array}{r}104 \\
56.5 \%\end{array}$ \\
\hline & 「趣味·仕事 & 12 & 5 & 6 & & 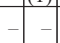 & & \begin{tabular}{c|c|c|c|}
5 & 13 \\
6
\end{tabular} & & - & 81 & 46.8 & 84 \\
\hline & 「家事 | & & 5 & & 6 & 2 & & & & 1 & $\frac{(3)}{34}$ & 19. & $\frac{.7 \%}{35}$ \\
\hline & & & & & & & (1) & & & & & & $19.0 \%$ \\
\hline & 「子遊び」 & & & 6 & & \begin{tabular}{c|c|c|}
2 & 16 \\
61
\end{tabular} \mid & & $5 \mid 13$ & & 116 & 63 & 36 & 666 \\
\hline \multirow{2}{*}{\multicolumn{2}{|c|}{ 総計 }} & \begin{tabular}{|l|l|}
45 & 12 \\
66 & $(1)$
\end{tabular} & & 6 & 6 & \begin{tabular}{l|l|}
2 & 16 \\
$(1)$
\end{tabular} & \begin{tabular}{|l|l|}
31 & 5 \\
\end{tabular} & \begin{tabular}{|l|l|}
5 & 13 \\
11
\end{tabular} & & 116 & & 100.0 & \\
\hline & & \multicolumn{5}{|c|}{$\begin{array}{r}9655.5 \\
10456.5 \%\end{array}$} & \multicolumn{4}{|c|}{$\begin{array}{r}7741.8 \\
8043.5\end{array}$} & & & \\
\hline
\end{tabular}

※( ) 内は榢族生活』の久老希望する11件の外数、斜体は「接客十家族重合」希望173件別 太字は『家族生活』希望のある全184件別の構成比を示寸

表 7 座敷（和室）に求める用途の重合性

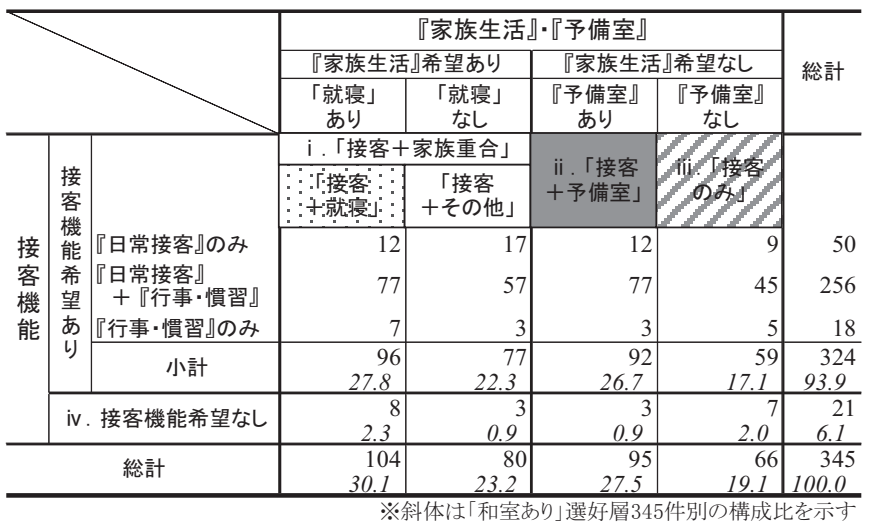




\section{2 ライフステージとの関係}

ライフステージ別で示唆的なのは、『家族生活』への希望であり、 「分寝前」での「就寝」希望は 43.1\%（50 件）で、その他のライフ ステージの約 2 倍である〈図 12$\rangle$ 。「子遊び」も同様に、「分寝前」 で 35.3\% (41 件) と高く、一方「趣味・仕事」は、「分寝以降」で 29.9\%（47 件）と最も高く希望されている。

希望用途の重合性で捉えると、「接客十家族重合」は「分寝前」で $62.9 \%$ と最も高く求められており、その後「分寝以降」 $46.5 \%$ 、「独 立別居」36.2\%では低い。これに対応して、「接客十予備室」は「分 寝前」以外で高く、「接客の夕」は「独立別居」において要求が高ま る〈図 13〉。すなわち、座敷（和室）に対する家族生活への用途は、

「分寝前」には、「就寝」を中心とした家族生活と接客との用途重合 が強く求められているが、「独立別居」期になると、接客のみ一の機 能分化の要求も高まり、これが前章で指摘した、ライフステージ後 期でのより高い「分離型」希望とも関わっていると考えられる。

5. 希望用途とプランタイプとの関係性についての分析

5.1 座敷（和室）に求める用途と選好プラン

1) 床の間の要否との関係

座敷（和室）への希望用途について、床の間の要否別の違いを捉 える。『行事・慣習』希望で違いがみられ、「床の間必要層」の「ZZ」・ 「WZ」では「仏間」74.7\%・80.8\%、「法事」69.6\%・65.4\%に対し、 「床の間不要層」の「ZW」・「WW」では「仏間」54.9\%・45.2\%、「法 事」 $49.0 \% \cdot 54.8 \%$ であり、いずれも後者が 2 3 割低い〈図 14〉。

仏間を設けることとそこで法事を行うことは、本来同一の営みで
あるから、一括して述べると、床の間の必要性は『行事・慣習』希 望の有無に強く起因していることが指摘できる。とはいえ、実数は 少なくとも「床の間不要層」の半数は、『行事・慣習』を希望し、ま た『日常接客』希望の有無では「床の間必要層」とは大きく違わな い点からみれば〈図 14〉、床の間の存在意義はさらに不明確化して いる側面もあることが指摘できる。

\section{2）選好プランとの関係}

床の間の要否で座敷 (和室) への希望用途が異なるが、以下では、 床の間温存層の「ZZ」237 件ついて、選好プラン別の分析を行う。

・和室数による違い

『日常接客』のうち「応対」が、「二室型」の「座十和続き間座敷 〈分 II〉」88.1\%、「座十和続き間座敷〈連 II 」9 $2.9 \%$ に対して、「一 室型」の「一つ間座敷〈分 I 」 $68.1 \%$ 、「座十洋続き間〈連 I A 」 $72.0 \%$ で低い〈図 16〉。同様に「祝い事」も、〈分 II $35.6 \%$ 、〈連 II〉 $50.0 \%$ に対し、〈分 I 〉 $14.5 \%$ 、〈連 I A〉19.5\%では約半数、これほど 顕著な差はないが、「就寝」も〈分 II $35.6 \%$ 、〈連 II $>35.7 \%$ に対し、

〈分 I〉 $23.2 \%$ 、〈連 I A〉 $29.3 \%$ と、「一室型」で希望度合が低い。

・リビングルームとの接続形式による違い

「子遊び」は「分離型」の〈分 II $16.9 \%$ 、〈分 I 〉 $11.6 \%$ に対し、 〈連 II $35.7 \%$ 、〈連 I A $20.7 \%$ と「連続型」で高い〈図 16〉。

以上を踏まえて希望用途の重合性を捉えると〈図 17〉、「接客十家 族重合」は、〈分 II 〉、〈連 II 、〈連 I A 〉では半数を超えるが、その 内訳は異なり、来客の「応対」や「祝い事」、た「就寝」希望は「二 室型」でより高く、一方「分寝前」で顕著にみられた「子遊び」に ついては、リビングルームとの続き間である〈連 I A 〉でより高い

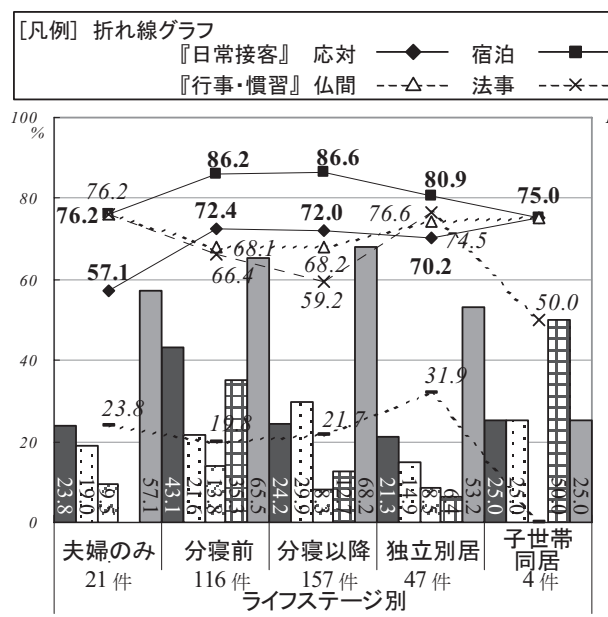

図 12 ライフステージ別 希望用途の傾向

\begin{tabular}{|c|c|c|}
\hline & 件 & 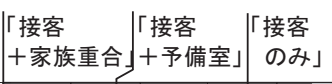 \\
\hline & 夫婦のみ 21 & $38.1 \mathrm{Mg}$ \\
\hline & 分寝前 116 & \begin{tabular}{|l|l|l|}
62.9 & 17.2 & $B 8$ \\
\end{tabular} \\
\hline if & 分寝以降 157 & 31.81 .59 \\
\hline & 独立別居 47 & $29.8 \mathrm{VZRO}$ \\
\hline iñ & 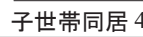 & 75.0 \\
\hline
\end{tabular}

図 13 ライフステージ別 希望用途の重合性

\section{棒グラフ} 『予備室』

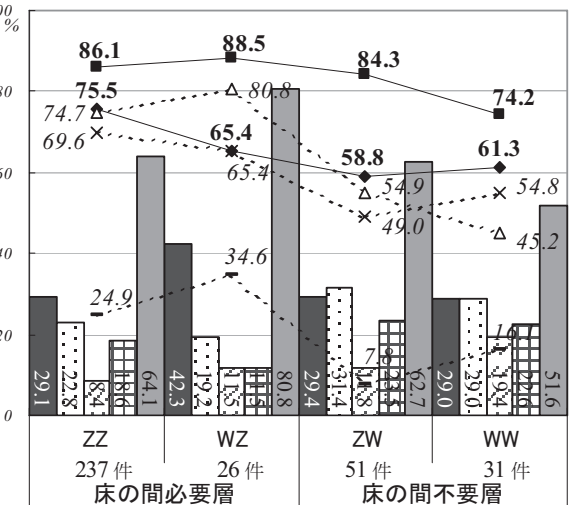

図 14 床の間の要否別 希望用途の傾向

\begin{tabular}{|c|c|c|c|c|}
\hline & $\langle$ 件 $\rangle$ & 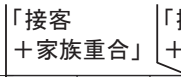 & $\begin{array}{l}\text { 接客 } \\
\text {-予備室」 }\end{array}$ & |「接客 \\
\hline \multirow{2}{*}{ 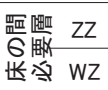 } & 237 & 49.8 & 27.8 & 27,3 \\
\hline & 26 & \multicolumn{2}{|c|}{61.5} & 30.87 \\
\hline \multirow{2}{*}{ 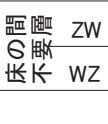 } & 51 & 49.0 & \multicolumn{2}{|c|}{$21.6 / 7,6$} \\
\hline & 31 & 45.2 & $22.6 \mathrm{C}$ & 94 \\
\hline
\end{tabular}

図 15 床の間の要否別 希望用途の重合性

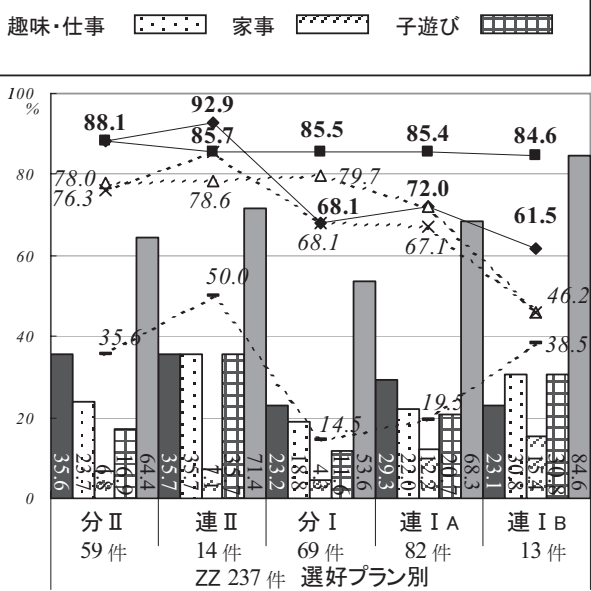

図 16 選好プラン別 希望用途の傾向

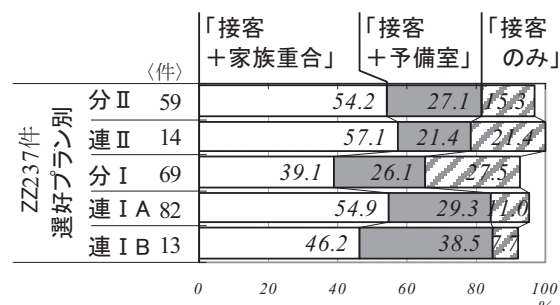

図 17 選好プラン別 希望用途の重合性 
希望が認められる。これに対し、「一つ間」の〈分 I〉への「接客十 家族重合」希望は $39.1 \%$ に留まり、「接客のみ」が $27.5 \%$ と高い。

\section{・「座十洋続き間（リビングアクセス）〈連 I B〉」の特殊性}

〈連 I B は は 13 件と少数であるが、座敷へのアクセスがリビング ルームからのみという他タイプとは異なる点、筆者らの予備的調査 (2006 年) ${ }^{12)}$ においてみられた、顕著な増加傾向を考慮し、この夕 イプに言及を加える。

〈連 I B は、『行事・慣習』のうち「仏間」・「法事」は $46.2 \%(6$ 件）であり、他タイプが 7 割前後であるのに比べ低いが、「祝い事」 （38.5\% 5 件）は「一室型」の他 2 タイプに比べ高い。また『予備 室』希望が 84.6\%（10 件）と高い等、廊下からも座敷へのアクセス が可能な〈連 I A 〉とは異なる值を示す点が注目される〈図 16〉。こ のことから、〈連 I B 〉の座敷が、現状でも、より家族生活領域化し ていると判断できる。これを接客にも対応させるという重合性を評 価する居住者には抵抗は薄いであろうが、これが〈連 I B 〉の居住・ 選好の不一致層の多さに結びついている要因であると考えられる。

\section{2 プランタイプの整合性と希望用途・ライフステージとの関係}

さらに「ZZ」について、居住・選好プランの整合性と、座敷に求 める用途、及びライフステージとの関係性について捉える。

\section{·「座十和続き間座敷〈分 II〉」居住者（22 件）について}

〈分 II 〉居住者は、選好との一致層の比率が高く、68.2\%（15 件） である。「接客十家族重合」の希望はこの一致層に集中し〈図 18〉、 「分寝以降」、独立別居」、「子世帯同居」である〈図 19〉。すなわ ち、座敷での家族生活（主に就寝や、趣味・仕事）への希望が〈分 II 〉支持の一要因であり、接客中心への希望層は、〈分 II〉 5 件と、 $\lceil$ 一室型」〈分 I〉 4 件、〈連 I A〉 2 件の縮小志向に二分する。

\section{·「一つ間座敷〈分 I 〉」居住者（64 件）について}

〈分 I〉居住者の選好との一致層は、60.9\%（39 件）であり、不

\begin{tabular}{|c|c|c|c|}
\hline \multirow[b]{2}{*}{$\begin{array}{l}\text { 居住 } \\
\text { プシ }\end{array}$} & \multirow[b]{2}{*}{ 選好 } & |座敷への希望用途の重合性 & |座敷への『日常接客』希望 \\
\hline & & \rangle$\left|\begin{array}{l|l|l}\text { 「接客 } \\
+ \text { 家族重合」接客 } \\
\text { 十予備室」 }\end{array}\right|$\begin{tabular}{c|c|} 
のみ \\
の客
\end{tabular} & $\begin{array}{l}\text { 改まつ|改まった客| } \\
\text { た親し } \\
\text { †宿泊 }\end{array}$ \\
\hline \multirow{4}{*}{$\begin{array}{l}\text { N } \\
\text { 鿉 }\end{array}$} & 分 II 15 & \multirow{2}{*}{\begin{tabular}{l|l|l|}
60.0 & $20.0 \quad 733$ \\
\end{tabular}} & 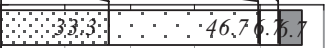 \\
\hline & I 4 & & $\begin{array}{ll}5 \theta & 75.0 \\
\end{array}$ \\
\hline & 連 II 1 & 100.0 & 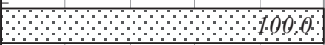 \\
\hline & 連 I A 2 & $Z \angle Z \angle O O$ & 50.0 \\
\hline \multirow{4}{*}{ t] } & 分II 16 & \begin{tabular}{|l|l}
50.0 \\
\end{tabular} & aldo \\
\hline & I 39 & $25.6 V / 3537.6$ & 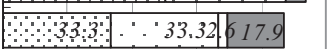 \\
\hline & 連 I A 8 & 62.5 & 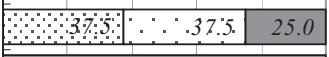 \\
\hline & 連 I B 1 & 100.0 & 100.0 \\
\hline \multirow{5}{*}{ 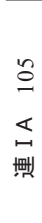 } & 分II 17 & $35.3 / 68 / 2$ & bs $\because$ \\
\hline & I 18 & \multirow{2}{*}{\begin{tabular}{l|l|l|}
55.6 & 22.2 & 1602 \\
66.7 & 1.1
\end{tabular}} & 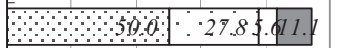 \\
\hline & 連 II 9 & & - \\
\hline & 連 I A 57 & 26.346 & 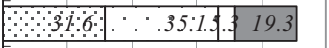 \\
\hline & 連 I B 4 & 50.0 & 250 \\
\hline
\end{tabular}

図 18 居住・選好プランの整合性と座敷への希望用途
一致層は〈分 II 〉への選好が $25.0 \%$ (16 件) で拡大志向が指摘でき、 〈連 I A 〉への連続志向は 12.5\%（8 件）のみである〈図 18〉。

「接客十家族重合」の希望は、一致層では 33.3\%（13 件）であり 〈図 18〉、他プランが半数を超える点と大きく異なる。この13 件中 8 件にみられる「就寝」希望のうち〈図 19〉、6 件が「分寝以降」、独 立別居」、「世帯同居」であり、これが一致層の一要因である。

不一致層は主として〈分 II〉を選好しており、これは基本的には 〈分 II 〉一致層と同様の理由によるものといえる〈図 19〉。これに 対して〈連 I A 〉選好、かつ「接客十家族重合」希望が 5 件あり、 うち 4 件が「分寝前」である点が特筆され〈図 19〉、就寝をはじめ、 リビングルームとの「連続型」に有用性を求める世帯である。

・「座十洋続き間〈連 I A〉」居住者（105 件）について

同一プラン〈連 I A 〉選好は 54.3\%（57 件）であり、不一致層は 〈分 I〉17.1\%（18 件）の分離志向、〈分 II〉16.2\%（17 件）の分離・ 拡大志向と、「分離型」への支持が顕著である〈図 18〉。一致・不一 致の要因は、希望用途の重合性からは単純には読み取れない。いず れも 9 割以上が接客機能を希望しているが〈図 18〉、『日常接客』希 望の内訳から、「改まった客」のみへの「応対」希望が、〈分 I 〉に 9 件 $(50.0 \%)$ にみられ、これが分離志向の一因として指摘できる。

さらにいずれも約半数みられる「接客十家族重合」の内訳から、 一致層〈連 I A 〉選好は、前述の〈分 I 〉 居住者の連続志向と同様、 「分寝前」が半数（34 件中 17 件）を占め〈図 19〉、「就寝」希望の 全 15 件中 9 件がこれにあたり、分寝前での就寝利用の有用性を評価 している世帯である。〈分 II 〉選好でも同様に「就寝」希望が 5 件認 められるが、「分寝前」(2 件) の他、「分寝以降」(3 件) でもみられ、 またこの 5 件中 3 件は「趣味・仕事」も併せて希望している点が、 分離・拡大志向の要因と言えよう。一方、〈分 I 〉選好では「趣味・ 仕事」が 6 件、中でも「分寝以降」で 4 件と多い点が指摘できる。

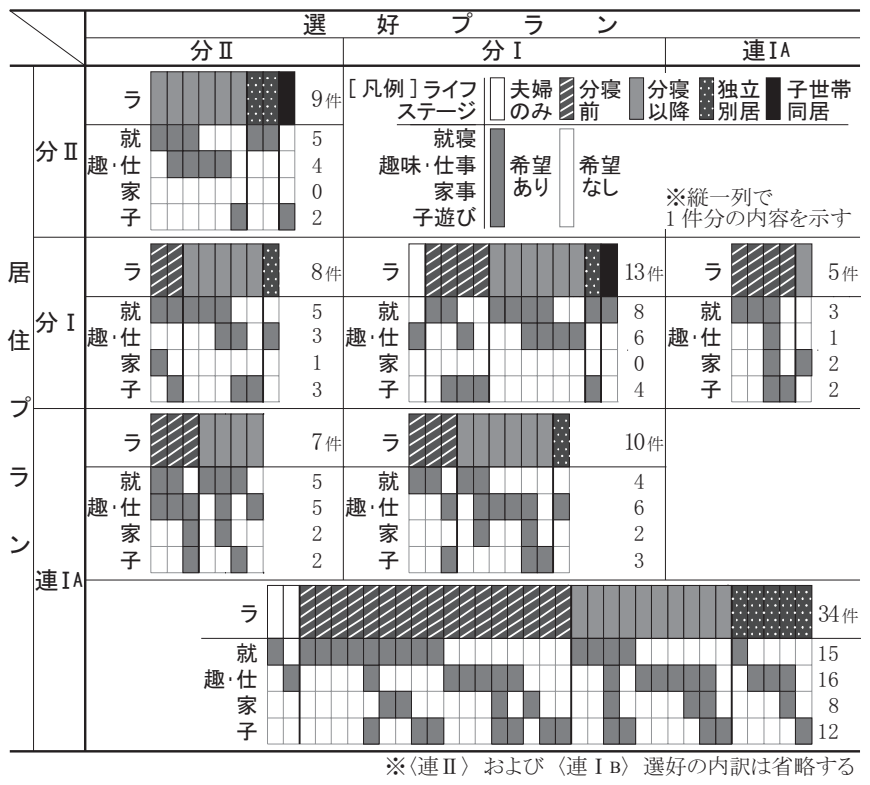

図 19 「接客十家族重合」希望者のライフステージと用途の詳細 


\section{6. まとめ}

i . 座敷をもちながら床の間を不要とする例が認められるものの、 温存志向は根強い。一方平面構成では、居住と選好の間に甚大な 乘離、寸なわち不一致層が存在しており、リビングルームからの 分離、「一室型」から「二室型」への拡大志向が顕著である。

ii . 座敷には依然、来客の応対や宿泊、仏間の設置や法事などの接 客機能が求められているが、就寝、趣味・仕事、家事・子育ての 機能も併せて求められており、先行研究[80’において、座敷を「実 際に使うことがある部屋」と捉えた世帯が約 1 割であった注 ${ }^{14)}$ の を考慮すると、座敷の家族領域化が著しく進行しているといえる。 iii. ライフステージ別にみると、「夫婦のみ」や、幼い子と両親が同 室就寝を行っている「分寝前」には、最も普及率の高い「座十洋 続き間〈連 I A 」への高い支持が認められるが、「分寝以降」や、 子が独立別居を果たし高年齢化した「独立別居後」では、「分離型」、 中でも「座十和続き間座敷〈分 II〉」への支持が高い。

iv .この傾向は座敷に求める用途からもよみとれ、〈連 I A〉は子ど もの遊びや、「分寝前」での就寝希望が高い。一方〈分II〉は「分 寝前」のみならず、その後のライフステージでも就寝希望がみら れ、また趣味・仕事への希望も高く認められる。

V ．すなわち、リビングルームと連続している〈連 I A 〉 は住宅 取得時に多い子の幼い世帯や家族人数の少ない世帯の住要求に対 しては、その有用性が評価されるが、その後のライフステージの 移行に伴う住要求の変化には対応できず、これが普及度に対して 低い評価、分離・拡大志向へとつながったと考えられる。

以上より、改めて現代の座敷の位置づけを考察すると、リビング ルームとは別に二間続きの座敷を確保する間取りは、歴史的には接 客本位性を意味するが、本稿で指摘した座敷の分離・拡大志向は、 近年のリビングルームでの来客の応対の一般化を考慮すると、必ず しも接客空間の重視でなく、むしろ家族空間の拡大、あるいは家族 空間である LDKからの接客空間の隔離を意味するように思われる。

もう一方の傾向として、床の間を不要とする和室志向の増加やこ れに顕著な連続志向、供給数の増加の傾向が認められる〈連 I B $〉 の$ 家族生活空間への要求の高さを指摘した。少数ではあるが、〈連 II 〉 の存在も考慮すると、前述の分離志向とは形態は異なるものの、こ れも座敷の家族領域化進行の反映であると推察される。

しかしながら、依然純粋な接客空間として座敷を求める層もあり、 この場合の居住・選好プランの整合性との関係については、住まい 手らの実際の接客行為や、その空間との関係性を探る必要がある。 また、床の間の要否については、接客利用と家族生活利用とで明確 な相関はみられず、現代における床の間の存在意義は単純なもので はなく、今後住まい方調查などを通じて解明すべき重要な課題であ る。鈴木（1984 年） ${ }^{13)}$ の指摘する、住宅の対社会性の重要性、閉鎖 化進行への危惧を念頭に、引き続き座敷の存亡を探る必要がある。

\section{謝辞}

本研究の調査にあたりご協力いただいた居住者の皆様をはじめ、 アンケート配布に協力してくださった各大学の先生および学生の 方々、大分大学鈴木研究室卒業生諸氏に心からお礼を申し上げます。

注

注 1) 来客の応対・宿泊、および慶尔祭祀が行われる空間を接客空間、食事やだん らん行為が行われる空間を家族空間、さらに就寝や個人の趣味・娛楽に利用さ れる空間を、私的空間と定義する。

注 2) 床の間を備えた和室を、座敷と定義する。

注3) 文献2)参照。なお、ここでのだんらん空間とは、家族の食事やだんらんの場で ある茶の間を核とする空間を指しており、[80’]において住宅の平面を類型する 際には、だんらん室として、DK (台所と食事室)または K (台所)に接続(半間以 上の開口で隣接)している部屋(和室も洋室も含む)をこれに定義している。

注 4) 1982 年、1983 年に、秋田県を除く 46 都道府県から新築独立住宅の新聞折り 込み広告を収集し、10532 件をサンプルとして接客空間確保の状況を全国規模 で把握しようとしたものである。文献 1)の (2) 現代研究編、および文献 2) 参照。

注 5) 注 4) と同様の調査を 1998 年〜2001 年に実施。全国 47 都道府県か 5602 件 のサンプルを収集し、住宅の平面構成の実態の解明を試みた。文献 3)参照。

注 6) DK または K に半間以上の開口で隣接する洋室を指す。

注 7) 文献 1)の (3) 現代研究編参照

注 8) 樋口は座敷を床の間付き和室、リビングルームを椅子式居間と呼称している。 注 9）世帯主夫婦とその子どもの就寝形態による類型をライフステージと定義する。

注 10) 平面構成 (平家, 3 階建て, 二世帯住宅) 、世帯構成 (独居,一人親世帯) 、居住 期間 (1990 年以前入居, 1 年未満) 等、比較考察する上で妥当性を欠くサンプルの 他、現在居住する住宅平面と選好する住宅平面の食い違いを明確にするため、 〈図 1〉に示す他、1 階に洋室や和室を持つプランは有効サンプルから除いた。 注 11) 延床面積の有効回答 237 件 $(64.2 \%)$ による值である。

注 12) 居室とは、DK 以外の室で 4.5 畳以下の室を除く室とする。

注 13)〈連 I B 〉および〈連 I B 和〉居住者の、〈連 I A および〈連 I A 和〉への選好は、 リビングルームのみでなく廊下からの座敷 (和室)へのアクセスも可能にするといら 意味で、「分離 $\left.{ }^{*}\right\rfloor$ 志向、その反対を「連続”」志向と定義する。

注 14) 1984 年、全国 47 都道府県を対象に実施された、必要とする接客室の形態と 座敷へのイメージについてのとしたアンケート調査。有効サンプル 3026 件のうち、 座敷を「格式・伝統的な部屋」と考えている例 $80.6 \%$ 、「実際に使うことがある部 屋」と実用的に捉えている例は 13.2\%であった。文献 1)の(3) 現代研究編参照。

\section{参考文献}

1) 九州大学青木研究室: 中流住宅の平面構成に関する研究 $(1) \sim(3)$, 住宅建築 研究所報, 第 10 号〜第 12 号, 1983 1985

2) 岡俊江、竹下輝和、青木正夫:接客空間とだんらん空間を指標とする類型化と平 面構成の考察〜現代の中流住宅の平面構成に関する研究 第 1 報 , 日本建 築学会計画系論文報告集, 第 383 号, pp.64〜 73, 1988

3) 岡俊江、鈴木義弘他:「座敷とだんらん空間からみた新築分譲住宅の平面構成 の変容過程に関寸る研究 第 1 報〜第 3 報, 第 6 報, 第 8 報」日本建築学会大 会学術講演梗概集, 2001〜2005

4) 鈴木成文、初見学:住居における公室の計画に関寸る研究, 住宅建築研究所報, No.8, pp.119 132, 1981

5) 江上徹:多目的空間としての居間の計画に関する研究, 住宅総合研究財団研究 年報, No.16, pp.105 120, 1989

6) 樋口栄作:4つの価值次元からみた接客性空間の価值づけ構造分析，日本建築 学会計画系論文報告集, 第456 号, pp.85 92, 1994

7) 笠嶋泰、今井正次、松本壮一郎: 重合住宅の住戸平面と接客・宿泊位置一ライ フステージによる住み方変化の研究 4-, 日本建築学会計画系論文報告集, 第 442 号, pp.47〜 55, 1992

8) 扇田信、西村一朗、今井範子:住様式に関する研究一床面様式と起居様式一, 住宅建築研究所報, No.5, pp. 47〜 70, 1978

9)平井ゆか、内田祥哉:畳と畳を支えるシステム開発と普及についての文献に関寸 る研究, 住宅総合研究財団研究年報, No.27, pp.263 274, 2000

10)服部岑生: 平面類型から見た住様式の動向に関寸る研究(1), 住宅建築研究所 報, No.7, pp.87〜116, 1980

11) 森本信明: 住宅金融公庫融資 (個人)を受けた戸建て住宅平面の研究（その 1）（その2), 日本建築学会計画系論文報告集, 第 444 号・第 451 号, pp.11 $20 \cdot 105 \sim 113,1993$

12）山口暁、鈴木義弘、切原舞子: 居間中心型住宅の急増の実証とその動向に関 する研究一大分市 $\mathrm{P}$ 団地における平面構成の経年変化をケースとして一, 日本 建築学会九州支部研究報告, 計画系 第 46 号, pp.41 44, 2007. 3

13) 鈴木成文:住居における対社会性の変遷と構造, 住宅建築研究所報, No.11, pp.145 157, 1984 